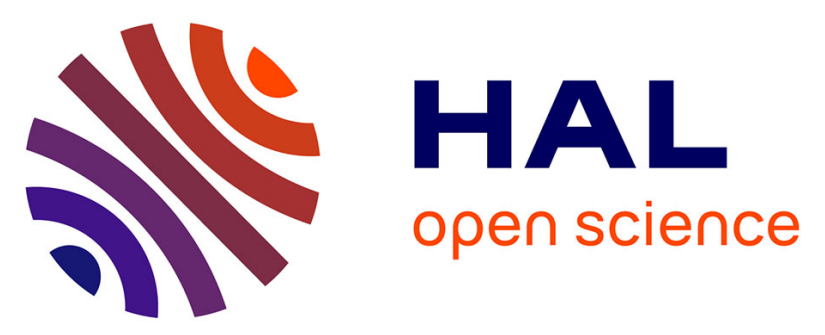

\title{
Non-aqueous gel polymer electrolyte with phosphoric acid ester and its application for quasi solid-state supercapacitors
}

\author{
Anna A. Łatoszyńska, Grażyna Zofia Żukowska, Iwona A. Rutkowska, \\ Pierre-Louis Taberna, Patrice Simon, Pawel J. Kulesza, Wladyslaw Wieczorek
}

\section{To cite this version:}

Anna A. Łatoszyńska, Grażyna Zofia Żukowska, Iwona A. Rutkowska, Pierre-Louis Taberna, Patrice Simon, et al.. Non-aqueous gel polymer electrolyte with phosphoric acid ester and its application for quasi solid-state supercapacitors. Journal of Power Sources, 2015, vol. 274, pp. 1147-1154. 10.1016/j.jpowsour.2014.10.094 . hal-01159400

\author{
HAL Id: hal-01159400 \\ https://hal.science/hal-01159400
}

Submitted on 3 Jun 2015

HAL is a multi-disciplinary open access archive for the deposit and dissemination of scientific research documents, whether they are published or not. The documents may come from teaching and research institutions in France or abroad, or from public or private research centers.
L'archive ouverte pluridisciplinaire HAL, est destinée au dépôt et à la diffusion de documents scientifiques de niveau recherche, publiés ou non, émanant des établissements d'enseignement et de recherche français ou étrangers, des laboratoires publics ou privés. 


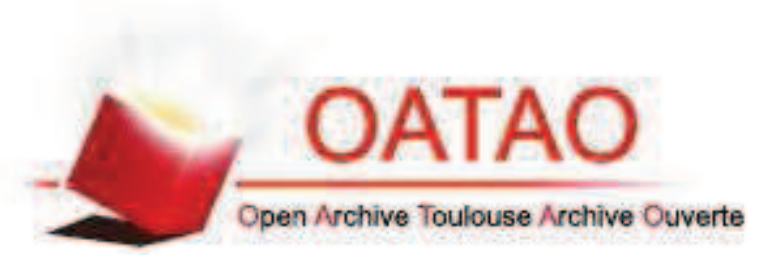

\section{Open Archive TOULOUSE Archive Ouverte (OATAO)}

OATAO is an open access repository that collects the work of Toulouse researchers and makes it freely available over the web where possible.

This is an author-deposited version published in : http://oatao.univ-toulouse.fr/ Eprints ID : 13902

To link to this article : doi:10.1016/j.jpowsour.2014.10.094

URL : http://dx.doi.org/10.1016/j.jpowsour.2014.10.094

To cite this version : Łatoszyńska, Anna A. and Żukowska, Grażyna Zofia and Rutkowska, Iwona A. and Taberna, Pierre-Louis and Simon, Patrice and Kulesza, Pawel J. and Wieczorek, Władysław Non-aqueous gel polymer electrolyte with phosphoric acid ester and its application for quasi solid-state supercapacitors. (2015) Journal of Power Sources, vol. 274. pp. 1147-1154. ISSN 0378-7753

Any correspondance concerning this service should be sent to the repository administrator: staff-oatao@,1istes-diff.inp-toulouse.fr 


\title{
Non-aqueous gel polymer electrolyte with phosphoric acid ester and its application for quasi solid-state supercapacitors
}

\author{
Anna A. Łatoszyńska a, c, *, Grażyna Zofia Żukowska a, Iwona A. Rutkowska ${ }^{\text {b }}$, \\ Pierre-Louis Taberna ${ }^{c}$, Patrice Simon ${ }^{c,}{ }^{d,}{ }^{* *}$, Pawel J. Kulesza ${ }^{b}$, Władysław Wieczorek ${ }^{\text {a }}$ \\ ${ }^{a}$ Faculty of Chemistry, Warsaw University of Technology, Noakowskiego 3, 00-664 Warsaw, Poland \\ ${ }^{\mathrm{b}}$ Faculty of Chemistry, University of Warsaw, Pasteura 1, 02-093 Warsaw, Poland \\ ' University Paul Sabatier, CIRIMAT, UMR-CNRS 5085, 31062 Toulouse Cedex 4, France \\ ${ }^{\mathrm{d}}$ Réseau sur le Stockage Electrochimique de l'Energie (RS2E), FR CNRS n³459, France
}

H I G H L I G H T S

- New proton-conducting gel polymer electrolyte has been proposed.

- Electrochemical capacitor with new electrolyte has been assembled and tested in wide temperature operation range.

- The capacity value $120 \mathrm{~F} \mathrm{~g}^{-1}$ has been reached at $22^{\circ} \mathrm{C}$ and $83 \mathrm{~F} \mathrm{~g}^{-1}$ at $-40{ }^{\circ} \mathrm{C}$.

Keywords:

Gel polymer electrolytes

Phosphoric acid ester

Electrochemical capacitor

Wide temperature range

\begin{abstract}
A B S T R A C T
A mechanically-stable non-aqueous proton-conducting gel polymer electrolyte that is based on methacrylate monomers, is considered here for application in solid-state type supercapacitors. An electrochemical cell using activated carbon as active materials and the new gel polymer electrolyte has been characterized at room temperature using cyclic voltammetry, galvanostatic charge-discharge cycle tests as well as impedance spectroscopy. The use of phosphoric acid ester (instead of phosphoric acid) as a proton donor has led to an increase of both the operation voltage window (up to $1.3 \mathrm{~V}$ ) and the electrolyte ionic conductivity (on the level of an order of magnitude). The resulting double layer capacitance of the microporous activated carbon was found to be as high as $120 \mathrm{~F} \mathrm{~g}^{-1}$; even more important, the supercapacitor utilizing non-aqueous proton-conducting gel polymer electrolyte is well-behaved in the wide temperature range (namely, from -40 to $80{ }^{\circ} \mathrm{C}$ ).
\end{abstract}

\section{Introduction}

There has been growing recent interest in electrochemical capacitors (ECs) as high-power charge-storage devices that could possibly act as alternative or a complementary energy systems to conventional secondary batteries. In comparison to batteries, ECs are typically characterized by lower specific energy but much higher specific power, in addition to longer cycle life [1-5].

Among important issues, there is a need to improve the EC's energy density, which is related to capacitance according to Eq. (1).

\footnotetext{
* Corresponding author. Faculty of Chemistry, Warsaw University of Technology, Noakowskiego 3, 00-664 Warsaw, Poland.

** Corresponding author. University Paul Sabatier, CIRIMAT, UMR-CNRS 5085, 31062 Toulouse Cedex 4, France.

E-mail addresses: aojrzynska@ch.pw.edu.pl (A.A. Łatoszyńska), simon@chimie. ups-tlse.fr (P. Simon).
}

$E=1 / 2 C V^{2}$

where $C$ stands for capacitance (in F), $V$ is the cell voltage (in V), and $E$ refers to energy (in J). A reasonable strategy for improving the energy density is to use highly capacitive materials. Among different systems of potential utility for Electrochemical Double Layer Capacitors (EDLCs), such carbon materials as activated, templated and carbide-derived carbons [6-9], carbon fabrics, fibers, nanotubes [10,11], onions [12], nanohorns [13] and graphene [14] have been considered. Highly effective pseudo-capacitive materials, such as metal oxides (i.e. $\mathrm{MnO}_{2}$ [15], $\mathrm{RuO}_{2}$ [16], $\mathrm{Nb}_{2} \mathrm{O}_{5}$ [17]) or conducting polymers (i.e. polyaniline (PANI), polypyrrole (PPy) [18]) that are characterized by fast electron transfers (between highly populated redox sites) responsible for their reversible charging/discharging processes, have also been proposed. 
Another option for increasing the energy density is to enlarge the cell voltage that is often limited by the electrolyte decomposition at high potentials. Indeed, most of commercial supercapacitors utilize non-aqueous organic electrolytes and, consequently, they can reach cell voltage as high as $3 \mathrm{~V}$ and they can operate at temperatures ranging from $-30^{\circ} \mathrm{C}$ to $60^{\circ} \mathrm{C}$.

Despite of these advantages of liquid organic electrolytes, application of semi-solid - rather than liquid - systems would be particularly advantageous because many problems related to packing issues, corrosion, self-discharge or leakage currents [19] could be solved. But the key issue is to maintain high ionic conductivity as well as good contact at the electrolyte-electrode interface. This requirement is of particular importance in a case of EDLCs where high surface area carbons are used as active materials. One of the solutions proposed to tackle these issues is the combination of liquid and polymer electrolytes to form gel polymer electrolytes (GPEs) [20-23].

In comparison to solid organic or inorganic electrolytes, GPEs have several advantages that include processability and flexibility of polymer matrices thus enabling the contact with the electrode surface. Hydrogels are gel electrolytes where an aqueous solution of $\mathrm{KOH}, \mathrm{H}_{2} \mathrm{SO}_{4}$ or $\mathrm{H}_{3} \mathrm{PO}_{4}$ is swollen within a polymer matrix based on poly(vinyl alcohol) (PVA) or polyacrylamide (PAAM) [24-26]. Thanks to their high ionic conductivity $\left(\sim 0.6 \mathrm{~S} \mathrm{~cm}^{-1}\right)$, the protonconducting hydrogel electrolytes have already been used for supercapacitor applications. Using gels based on PVA [27-30], Lian et al. demonstrated high-rate capability and cyclability thanks to high ionic conductivity of the PVA gel $\left(0.02 \mathrm{~S} \mathrm{~cm}^{-1}\right)$; however, the use of non-porous carbons limited the cell capacitance and energy. Stępniak et al. reported capacitance as high as $130 \mathrm{~F} \mathrm{~g}^{-1}$ for activated carbons in PAAM based electrolytes together with $\mathrm{H}_{2} \mathrm{SO}_{4}$ aqueous solution. However, due to the presence of water, the operation voltage window $(0.8 \mathrm{~V})$ and indirectly the device energy density (3.5 $\mathrm{Wh} \mathrm{kg}^{-1}$ ), as well as the operation temperature range [24] were deeply affected.

An important alternative arises from the possibility of replacing water as a solvent in proton-conducting gel-electrolytes with the combination of propylene carbonate (PC) and N,Ndimethylformamide (DMF). Consequently, both the stability windows (up to $1.5 \mathrm{~V}$ ) and the temperature operation range (from $-40{ }^{\circ} \mathrm{C}$ to $80{ }^{\circ} \mathrm{C}$ ) can be improved [31,32]. Besides the choice of solvent, both the polymer host and the proton donor are of high importance. The polymer matrix should be an inert element in GPE, so the monomers, which react with proton donor should be rejected. In the presence of strong acids, such as $\mathrm{H}_{2} \mathrm{SO}_{4}$ or $\mathrm{H}_{3} \mathrm{PO}_{4}$, the degradation of the $\mathrm{C}-\mathrm{O}$ bond in polyethers or polyalcohols is feasible; moreover, the stability window tends to decrease down to $1 \mathrm{~V}$ in the presence of $\mathrm{H}_{3} \mathrm{O}^{+}$ions. For instance, Morita et al. prepared non-aqueous GPEs from poly(ethylene oxide)-modified polymethacrylate (PEO-PMA) matrix and anhydrous $\mathrm{H}_{3} \mathrm{PO}_{4}$ [33]. But the use of high concentration of phosphoric acid limited the electrolyte potential window down to $1 \mathrm{~V}$. In this respect, it is reasonable to consider aryl phosphates as alternatives to orthophosphoric acid. Indeed, many phosphoric acid esters have strong acid properties: e.g. the $\mathrm{pK}_{\mathrm{a}}$ of monophenyl phosphate value is even lower than that characteristic of phosphoric acid. In addition, such features as miscibility with polar solvents and chemical compatibility with polymers make phosphoric acid esters good candidates for the replacement of phosphoric acid in GPEs [34].

In the present work, we explore proton-conducting GPEs based on methacrylate copolymer matrix for application in Electrochemical Double Layer Capacitors (EDLC). At first, we report the preparation and physicochemical characterizations of the GPE in which phosphoric acid has been replaced by its ester (diphenyl phosphate) as a proton donor. The ionic conductivity and mechanisms of proton transport have been studied using thermal stability analysis. Finally, the electrochemical characterization of a supercapacitor cell using activated carbon electrodes and the GPE electrolyte has been achieved in a large temperature range (from $-40^{\circ} \mathrm{C}$ to $80^{\circ} \mathrm{C}$ ).

\section{Experimental}

\subsection{Materials}

Monomers: methyl methacrylate (MMA), 2-hydroxyethyl methacrylate (HEMA) (Sigma Aldrich); cross linking agent: triethylene glycol dimethacrylate (TEGDM) (Sigma Aldrich); proton donor: diphenyl phosphate $\left(\mathrm{DPhHPO}_{4}\right)$ (Sigma Aldrich, 99\%) Scheme 1; solvents: propylene carbonate (PC) (Sigma Aldrich, anhydrous) and N,N-dimethylformamide (DMF) (Sigma Aldrich, anhydrous) were used without further purification. Radical polymerization initiator: benzoyl peroxide (BP) (Sigma Aldrich) was recrystallized from chloroform and dried under vacuum. Carbon material: activated carbon YP-80F was from Kuraray Chemical Co., LTD (SSA $2145 \mathrm{~m}^{2} \mathrm{~g}^{-1}$ ); and poly(vinylidene fluoride-hexafluoropropylene) (PVdF-HFP) was used as a binder.

\subsection{Preparation of the gel electrolyte}

Gel polymer electrolyte (GPE) was prepared in a glove-box under Ar atmosphere by mixing PC with monomers (MMA and HEMA), the initiator (BP) and the cross-linking agent (TEGDM). After stirring for $1 \mathrm{~h}$, the solution was cast as a thin film $(\sim 200 \mu \mathrm{m})$ on a glass plate and placed in oven at $60-70{ }^{\circ} \mathrm{C}$ for gelation $(12 \mathrm{~h})$. The next step was soaking the film with a solution of $\mathrm{DPhHPO}_{4}$ in DMF and left for 1 week. Various electrolytes were prepared, containing $12.5 \mathrm{wt} . \%$ polymer matrix (HEMA:MMA ratio of 60:40 wt.\%), various concentrations of $\mathrm{DPhHPO}_{4}$ (from 5 to $40 \mathrm{wt}$.\% in the final concentration of GPEs), and solvent mixture (PC:DMF ratio of 70:30 wt.\%). Appropriate amounts of BP (1 wt.\%) and TEGDM (5 wt.\%).

\subsection{Electrodes and cell preparation}

The composite carbon electrodes were prepared by mixing the activated carbon with $5 \mathrm{wt}$.\% PVdF-HFP binder in acetone. The activated carbon was a YP-80F from the Kuraray company. It is a microporous carbon, with a high specific surface area of $2145 \pm 16 \mathrm{~m}^{2} \mathrm{~g}^{-1}$. Ar gas sorption measurements have shown that the carbon structure contains mainly micropores (pore diameter lower than $2 \mathrm{~nm}$ ), accounting for $87 \%$ of the total pore volume and mesopores in the $2-7 \mathrm{~nm}$ diameter range. $50 \%$ of the micropores is lower than $1 \mathrm{~nm}$. The slurry was casted onto Au disks (thickness, $\sim 60 \mu \mathrm{m}$; surface area, $\sim 1.29 \mathrm{~cm}^{2}$ ), placed in vacuum oven and dried at $120{ }^{\circ} \mathrm{C}$. The carbon mass loading was $2.0 \mathrm{mg} \mathrm{cm}^{-2}$. Symmetric cells were assembled using Swagelok ${ }^{\circledR}$, and GPE was placed between two opposing electrodes. To improve the contact between electrode and solid electrolyte, carbon electrodes were wetted with few drops of solvent mixture (in which DMF was on 30 wt.\% level).

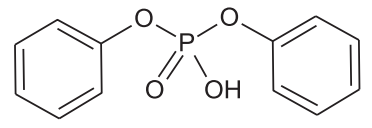

Scheme 1. The structure of diphenyl phosphate. 


\subsection{Experimental techniques}

Ionic conductivity was determined using an impedance spectroscopy method (EIS) in the temperature range from -30 to $90^{\circ} \mathrm{C}$. The samples were sandwiched between two stainless steel blocking electrodes and placed in the temperature-controlled thermostat. Electrochemical measurements were done using a VMP Multichannel Potentiostat (VMP, Biologic Science Instrument, France) over the frequency ranging from 10 to $500 \mathrm{kHz}$.

The infrared (IR) spectra were recorded with a computerinterfaced Perkin Elmer 2000 FT-IR system in the wave number range from $400 \mathrm{~cm}^{-1}$ to $4000 \mathrm{~cm}^{-1}$. The electrolytes were sandwiched between two $\mathrm{NaCl}$ pellets.

Differential Scanning Calorimetry (DSC) studies were performed in the -150 to $150{ }^{\circ} \mathrm{C}$ temperature range using DSC Q200 V24.2 Build 107 system equipped with low-temperature measuring head and liquid helium cooling element. Samples were loaded into aluminum pans and stabilized by cooling from the room temperature down to $-150{ }^{\circ} \mathrm{C}$. Samples were then heated at $20{ }^{\circ} \mathrm{C} \mathrm{min}-1$ rate up to $150{ }^{\circ} \mathrm{C}$; an empty pan was used as a reference.

Electrochemical measurements were achieved at various temperatures (ranging from from -40 to $80^{\circ} \mathrm{C}$ ) using a Votsch climatic chamber (Germany). Before starting electrochemical measurements, the cells were kept for $4 \mathrm{~h}$ until the desired temperature was reached, which was found to ensure that the cell temperature was the same as that of the chamber [35]. Electrochemical impedance spectroscopy measurements of capacitor cells were achieved between $100 \mathrm{kHz}$ and $1 \mathrm{mHz}$. Cycling voltammetry (CV) experiments were performed at the scan rates of 1,5 and $10 \mathrm{mV} \mathrm{s}^{-1}$; and the constant current charge/discharge tests (GCPL) were carried upon application of $0.075 \mathrm{~A} \mathrm{~g}^{-1}$.

The gravimetric capacitance $C_{\text {am }}$ of active material (in $\mathrm{F} \mathrm{g}^{-1}$ ) was calculated from the cell capacitance $(C)$ using the equation:

$C_{\mathrm{am}}=\frac{2 C}{m_{\mathrm{am}}}$

where $m_{\mathrm{am}}$ was the weight of the active material (carbon) per electrode $(\mathrm{g})$.

The cell capacitance was calculated by measuring the slope of a charge $Q$ versus voltage $V$ plot. Charge was calculated from the integration of the $\mathrm{CV}$ plots recorded during the discharge step. The cell capacitance was also calculated from the slope of the galvanostatic discharge plots using the equation below:

$C=\frac{I}{\frac{\mathrm{d} V}{\mathrm{~d} t}}$

where $C$ was the capacitance of the cell (in F), $I$ was the discharge current (in $\mathrm{A}$ ), and $\mathrm{d} V / \mathrm{d} t$ was a slope of the discharge curve (in $\left.\mathrm{V} \mathrm{s}^{-1}\right)$.

\section{Results and discussion}

\subsection{Electrolyte characterization}

Prepared methacrylate-based polymer gel electrolytes are transparent and freestanding membranes (Fig. 1); they show high flexibility and good mechanical stability. The elastic properties depend on the solvent content [36] and the main role of polymer matrix is to assure good structural integrity [31]. It is generally accepted that the ion conduction mechanism in gel electrolytes is similar to that of liquid systems. In other words, the solvent acts as the main conduction medium in the gel system. Although such important physical features of proton conducting gels, as high

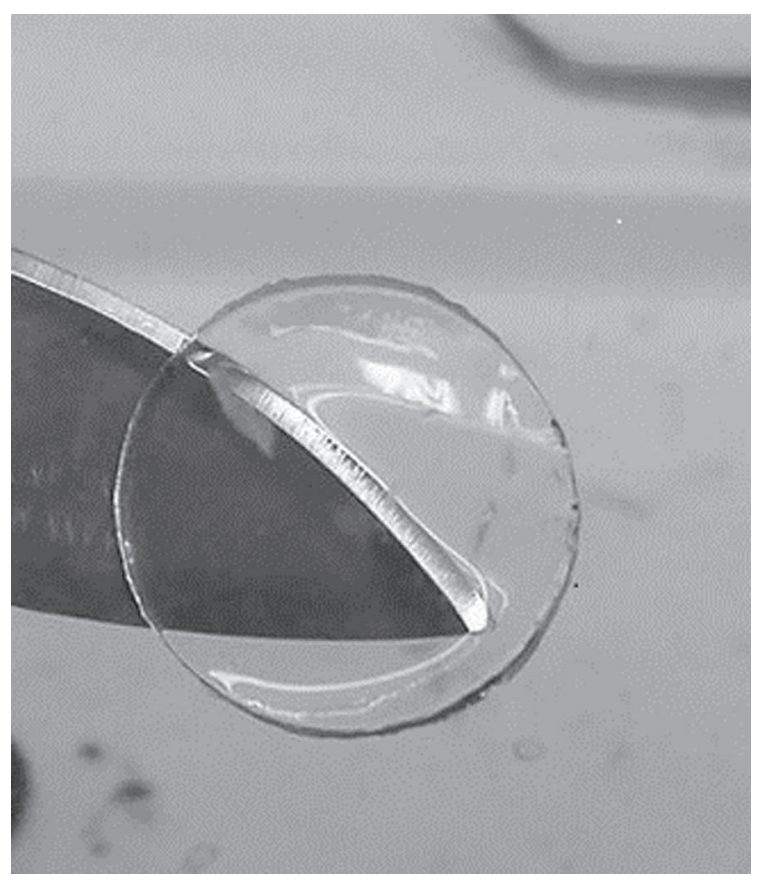

Fig. 1. Pictures of methacrylate-based GPE used as separator.

dielectric constant, low viscosity and wide operation temperature range [36-38] should be appreciated, the possibility of the protonation of solvent molecules by the proton dopant is the next important factor.

Two methacrylate monomers have been chosen in the present work: methyl methacrylate (MMA) and 2-hydroxyethyl methacrylate (HEMA). HEMA is widely used for biocompatibility and hydrophilicity in separation techniques, chemical sensors and biomaterials [39-42]. Each monomer was used before as polymer matrix in proton conducting systems [31,43] and no reaction between $\mathrm{P}-\mathrm{OH}$ group and polymer chain was noticed. However based on comparison of the proton conductivities in gel and liquid systems, the slight decrease was observed in a gel. The reason for lower conductivity in gel originates from entrapping of liquid phase in polymer matrix: this results in higher viscosity and decrease of the mobility of charge carries. It was shown that with decreasing the polymer content in gel, the conductivity increased, combined with the decrease in viscosity of samples [36].

Fig. 2a illustrates the temperature dependence of conductivity recorded for the gel electrolyte utilizing $\mathrm{P}$ (HEMA-co-MMA), PC-DMF mixture (30 wt.\% of DMF) doped with $\mathrm{H}_{3} \mathrm{PO}_{4}$ and diphenyl phosphate (proton donor contents, 5 and 15 wt.\%). Within the entire temperature range (from 20 to $90{ }^{\circ} \mathrm{C}$ ), the conductivity values of GPE doped with phosphoric acid ester are higher than those obtained with $\mathrm{H}_{3} \mathrm{PO}_{4}$ (at the same mass content). The increase in conductivity can be explained by the increase in acidity of partial esters (in comparison to $\mathrm{H}_{3} \mathrm{PO}_{4}$ ). The substitution of acidic protons by aryl groups decreases the electron density on oxygen thus resulting in weakening of $\mathrm{H}-\mathrm{O}$ bonds and increasing the acid dissociation. Fig. $2 b$ shows the dependence of ionic conductivity as a function of inverse temperature recorded for gel electrolytes doped with diphenyl phosphate. Above temperatures ca. $-20{ }^{\circ} \mathrm{C}$, the conductivity increases with the concentration of proton (from 5 to $40 \mathrm{wt} . \%$ ). Below $-20{ }^{\circ} \mathrm{C}$, the decrease in conductivity with increasing proton concentration is observed. 

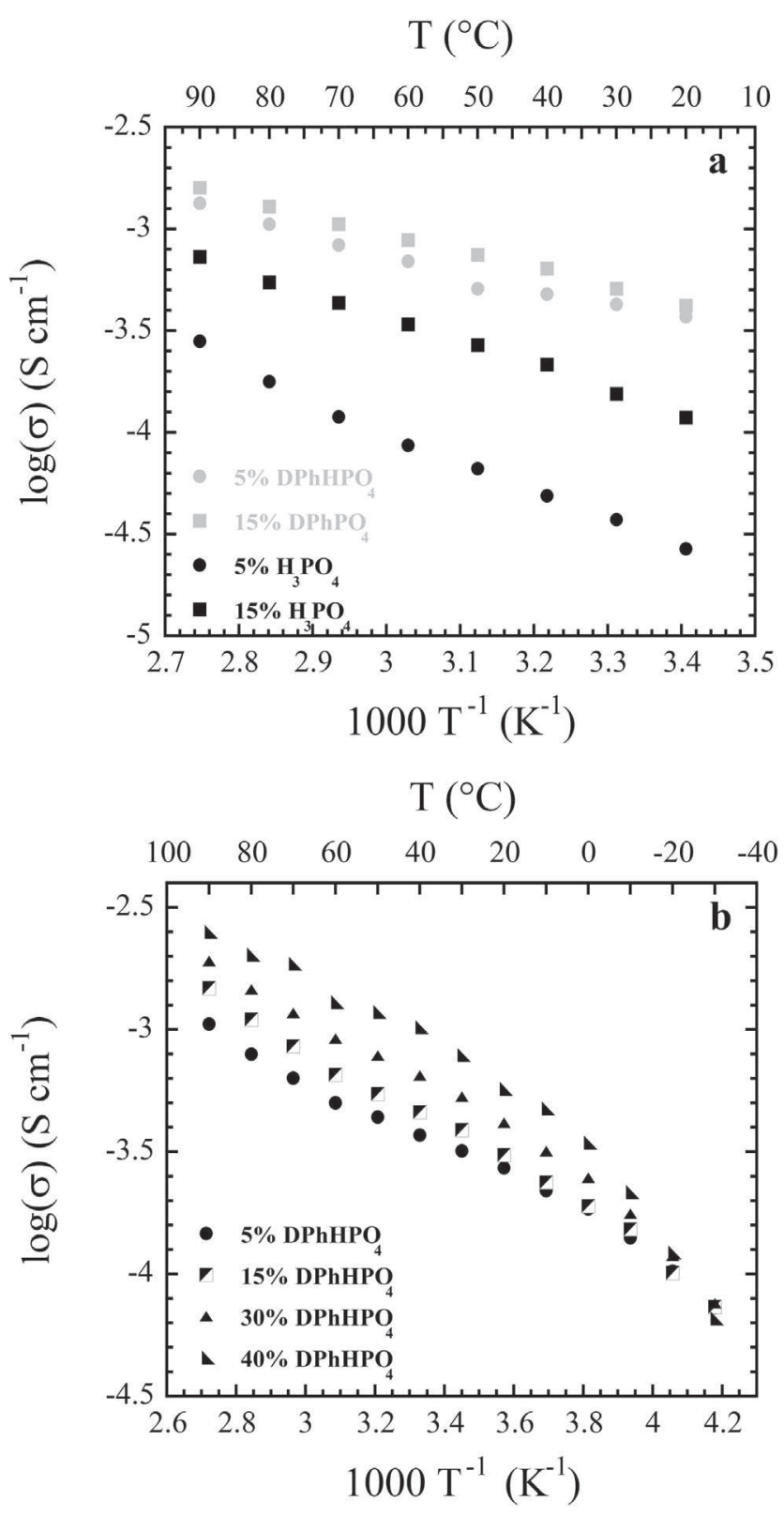

Fig. 2. Ionic conductivity electrolytes as a function of inverse temperature for the $\mathrm{P}$ (HEMA-co-MMA) based gel electrolytes containing different concentration of proton donor, where a) a comparison of $\mathrm{H}_{3} \mathrm{PO}_{4}$ and $\mathrm{DPhHPO}_{4}$ and b) different concentration of $\mathrm{DPhHPO}_{4}$. Samples contains 12.5 wt.\% of polymer (where $60 \mathrm{wt} . \%$ is HEMA and 40 wt.\% MMA) in DMF-PC solvent mixture (30 wt.\% of DMF).

The change of the conductivity with $1 / T$ follows an Arrhenius's law; the values of activation energy $\left(E_{\mathrm{a}}\right)$ have been calculated using Eq. (4) and collected in Table 1:

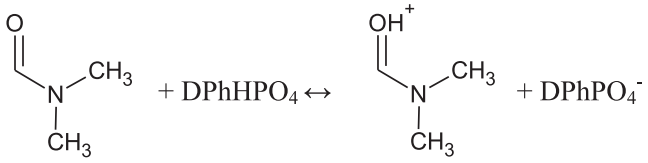

Scheme 2. The mechanism of proton transport in DMF.

$\sigma(T)=\frac{\sigma_{\infty} \exp \left(-E_{a}\right)}{k_{B} T}$

where, $E_{\mathrm{a}}$ is the activation energy (in $\mathrm{J} \mathrm{mol}^{-1}$ ), $\sigma_{\infty}=\lim _{T \rightarrow \infty} \sigma(T)$ and $k_{\mathrm{B}}$ is the Boltzmann constant $\left(1.38 \times 10^{-23} \mathrm{~m}^{2} \mathrm{~kg} \mathrm{~s}^{-2} \mathrm{~K}^{-1}\right)$. The activation energy value is one of the parameters helping to define the mechanism of proton transport. The previous works of Wieczorek et al. have pointed on PC and DMF as the most appropriate solvents [36]. DMF is a protophilic solvent by itself that contributes to proton conduction according to the Grotthus-type proton-exchange conduction transport. This mechanism leads to lowering the activation energy for proton conduction and increasing the conductivity. PC molecules cannot be easily protonate and, therefore, the proton transport takes place via vehicle-type mechanism in this protophobic solvent; consequently, the charge carriers are polyatomic molecules of proton donor in the latter mechanism. The lower proton conductivity in PC based systems can be assigned to lower charge mobility because of the solvent's higher viscosity (2.5 cP) in comparison to DMF (0.8 cP) [36].

The $E_{\mathrm{a}}$ decrease may suggest Grotthus - type mechanism to be operative in the system. Żukowska et al. examined the diphenyl phosphate based GPE with PC as a solvent [34]. Comparison of the $E_{\mathrm{a}}$ data $\left(27.5 \mathrm{~kJ} \mathrm{~mol}^{-1}\right.$ for the proton donor concentration at $5 \mathrm{wt} . \%$ level) [34] obtained in the PC based GPE with results obtained in the PC-DMF solvents mixture $\left(\sim 18 \mathrm{~kJ} \mathrm{~mol}^{-1}\right)$ (Table 1$)$ clearly indicates the decrease in mixed solvents. The $E_{\mathrm{a}}$ values are consistent with the protonation of DMF molecule taking place in the presence of the mixture of protophilic and protophobic solvents (Scheme 2). The proton transport is achieved via a Grotthus type mechanism, as previously observed in GPE with phosphoric acid as a proton donor [36].

The FT-IR spectra of crystalline ester were obtained to get a better insight into the conduction mechanism. Because polymer matrix is not involved in the conduction mechanism, the spectra were compared to those of liquid solutions at the different ester contents in the PC-DMF solvents only.

The protonation of DMF particle, observed in the phosphoric acid based GPE, takes place also in esters. The broadening of the $\mathrm{U}_{\mathrm{C}}={ }_{\mathrm{O}}$ peak of solvent and a shift of this band, as well as shifts in the positions of 1407 and $1094 \mathrm{~cm}^{-1}$ peaks, typically attributed to $\delta_{\mathrm{C}-\mathrm{H}}$ and $\gamma_{\mathrm{C}-\mathrm{H}}$ vibrations, were observed in acid solutions in pure DMF [32]. The FT-IR spectra taken for different mono- and diesters in DMF also confirmed protonation of DMF particle [34]. However, in solvent mixtures, the content of DMF is rather too small and any significant changes were observed even with the highest ester

Table 1

Conductivities of polymer electrolytes containing $\mathrm{DPhHPO}_{4}$ solutions together with calculated activation energy values $\left(E_{\mathrm{a}}\right)$ and the glass transition temperatures determinate by DSC $\left(T_{\mathrm{g}}\right.$ ). Samples contains $12.5 \mathrm{wt} . \%$ of polymer matrix and PC-DMF (30 wt.\% of DMF in solvent mixture).

\begin{tabular}{|c|c|c|c|c|c|}
\hline Polymer matrix & Solvent & $\begin{array}{l}\text { Diphenyl phosphate } \\
\text { concentration (wt.\%) }\end{array}$ & $\sigma\left(\mathrm{S} \mathrm{cm}^{-1}\right)$ at $20^{\circ} \mathrm{C}$ & $E_{\mathrm{a}}\left(\mathrm{kJ} \mathrm{mol}^{-1}\right)$ & $T_{\mathrm{g}}\left({ }^{\circ} \mathrm{C}\right)$ \\
\hline $\begin{array}{l}\text { P (MMA-co-HEMA) } \\
\text { (60 wt.\% of HEMA) }\end{array}$ & $\begin{array}{l}\text { PC }- \text { DMF } \\
\text { (30 wt.\% of DMF) }\end{array}$ & $\begin{array}{r}5 \\
15 \\
30 \\
40\end{array}$ & $\begin{array}{l}2.7 \times 10^{-4} \\
3.1 \times 10^{-4} \\
4.2 \times 10^{-4} \\
5.7 \times 10^{-4}\end{array}$ & $\begin{array}{l}16.4 \\
19.1 \\
18.6 \\
18.0\end{array}$ & $\begin{array}{r}-109 \\
-93 \\
-91 \\
-83\end{array}$ \\
\hline
\end{tabular}


concentration. Therefore, to confirm proton conducting mechanism, the spectra regions characteristic for $\mathrm{P}=\mathrm{O}, \mathrm{P}-\mathrm{O}-\mathrm{C}$ and $\mathrm{P}-\mathrm{O}-\mathrm{H}$ should be analyzed [34].

Fig. 3a illustrates the region between 1300 and $800 \mathrm{~cm}^{-1}$, corresponding to vibrations characteristics of organic phosphates. In the spectra of diphenyl phosphate, the bands with the strong intensity can be distinguish and assigned to $\mathrm{P}=\mathrm{O}, \mathrm{P}-\mathrm{O}-\mathrm{H}$ and $\mathrm{P}-\mathrm{O}-\mathrm{C}$ stretching vibrations. The $\mathrm{U}_{\mathrm{P}}=\mathrm{O}$ band appears at $1273 \mathrm{~cm}^{-1}$
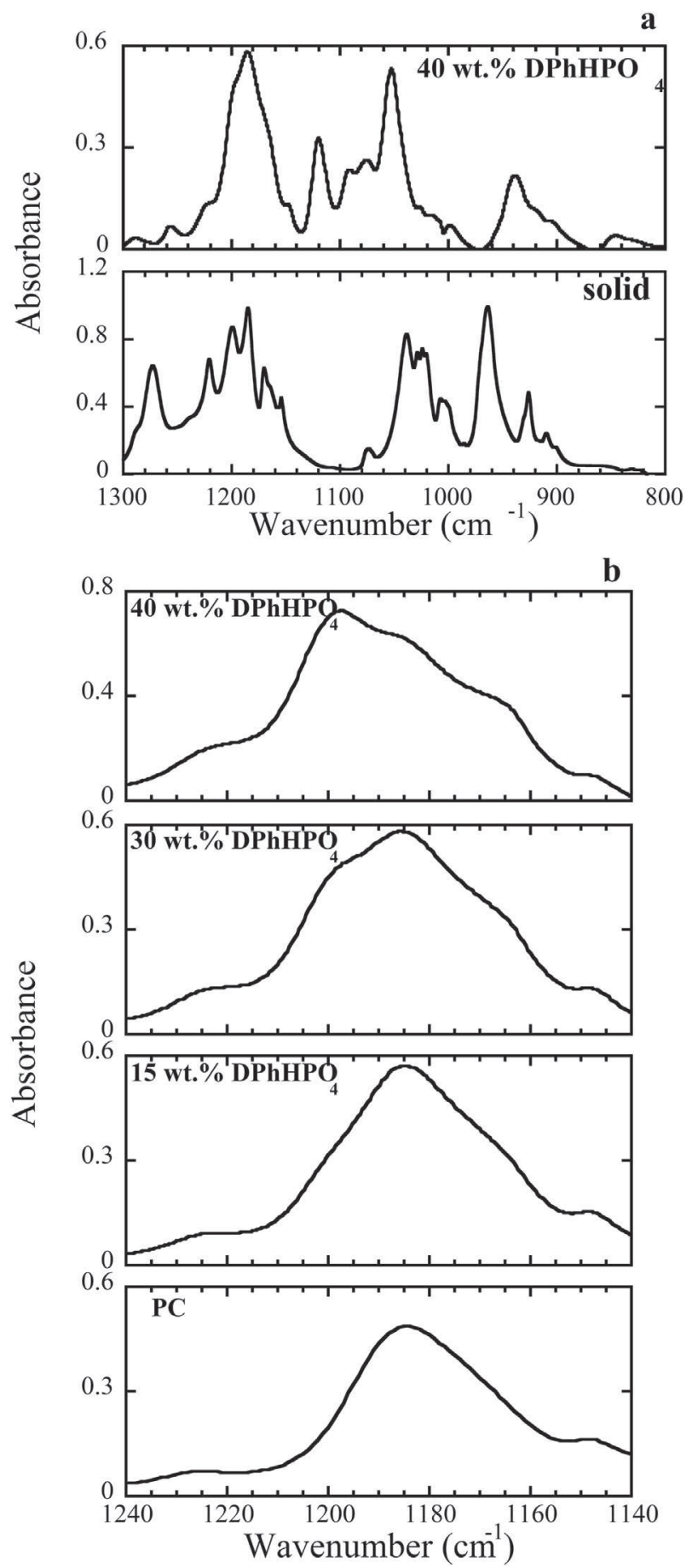

Fig. 3. A comparison of FTIR spectra of crystalline ester (dotted line) with DPhHPO4PC-DMF solutions containing different ester concentration a) region characteristic for ester vibrations b) the influence of a solvent on the position of diphenyl phosphate characteristic bands.
[44] in the solid compound; on the other hand, this band is largely masked by a stronger band of PC in a case of the solutions spectra. The appearance of a strong solvent band should be noted here. When compared to the pure component, a shift of $u_{\mathrm{P}-\mathrm{O}-\mathrm{H}}$ to lower frequencies with increase of ester concentration (from 1200 to $1197 \mathrm{~cm}^{-1}$ ) can be observed (Fig. 3b). This change in the peak position is indicative of the loss of hydrogen bonds between the ester molecules, and it indirectly implies protonation of the solvent. In the ester solution ( $40 \mathrm{wt} . \%$ ), the peaks corresponding to $\mathrm{v}_{\mathrm{P}-\mathrm{OC}}$ and $U_{\mathrm{PO}-\mathrm{C}}$ stretching can be observed and their positions are almost unaffected. A band, that shall be attributed to $\mathrm{P}-\mathrm{O}-\mathrm{C}$ stretching vibrations of diphenyl phosphate, appears at 963 (in solid) and $938 \mathrm{~cm}^{-1}$ (in solution containing the ester at $40 \mathrm{wt} . \%$ ). The band position is not affected by the concentration of ester.

To comment on the operational temperature range and the electrolyte's thermal stability, Differential Scanning Calorimetry (DSC) measurements were done. Table 1 presents the DSC data obtained for polymer gel electrolytes containing the proton donor at different concentrations. The only phase transition occurring in the -150 to $150{ }^{\circ} \mathrm{C}$ temperature range is the glass temperature transition, as demonstrated in Fig. 4 for the $15 \mathrm{wt} . \%$ $\mathrm{DPhHPO}_{4}$. The thermal properties of GPE are mostly affected by the presence and concentrations of the solvent and the proton donor. In the present work, however, the solvent content was constant, so that the change in thermal properties reflected the concentration of the proton donor. The increase of the diphenyl phosphate concentration resulted in stiffening of the system (that presumably reflected interactions with solvent and polymer matrix), and thus leading to changes in $T_{\mathrm{g}}$ values. The lowest value of $T_{\mathrm{g}}$ were obtained for the sample containing $5 \%$ of ester, and the increase of the proton donor content resulted in an increase in $T_{\mathrm{g}}$.

\subsection{Electrochemical double layer capacitor characterization}

The proposed and synthesized GPE electrolytes (as described in Experimental section) were further used to assemble EDLC cells, namely by sandwiching the casted electrolytes between two activated carbon electrodes. The semi-solid proton-conducting gel acted as mechanically stable separator. The system with a content

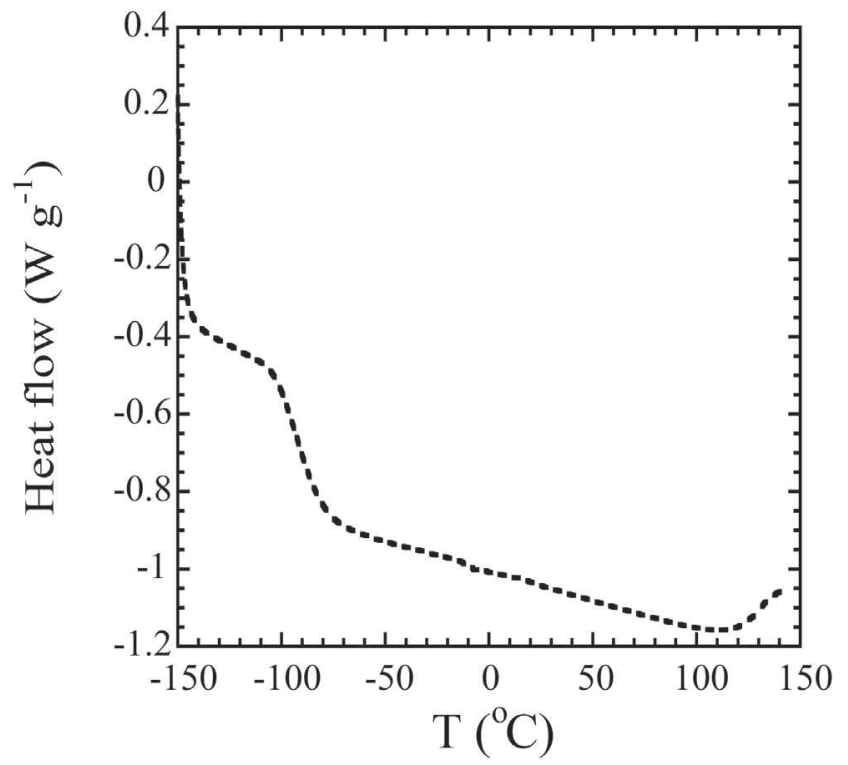

Fig. 4. DSC plot for $\mathrm{P}(\mathrm{HEMA}-\mathrm{Co}-\mathrm{MMA}$ ) based electrolyte (where $12.5 \mathrm{wt}$ \% is polymer matrix) with 15 wt.\% of diphenyl phosphate content and PC-DMF solvent mixture. 

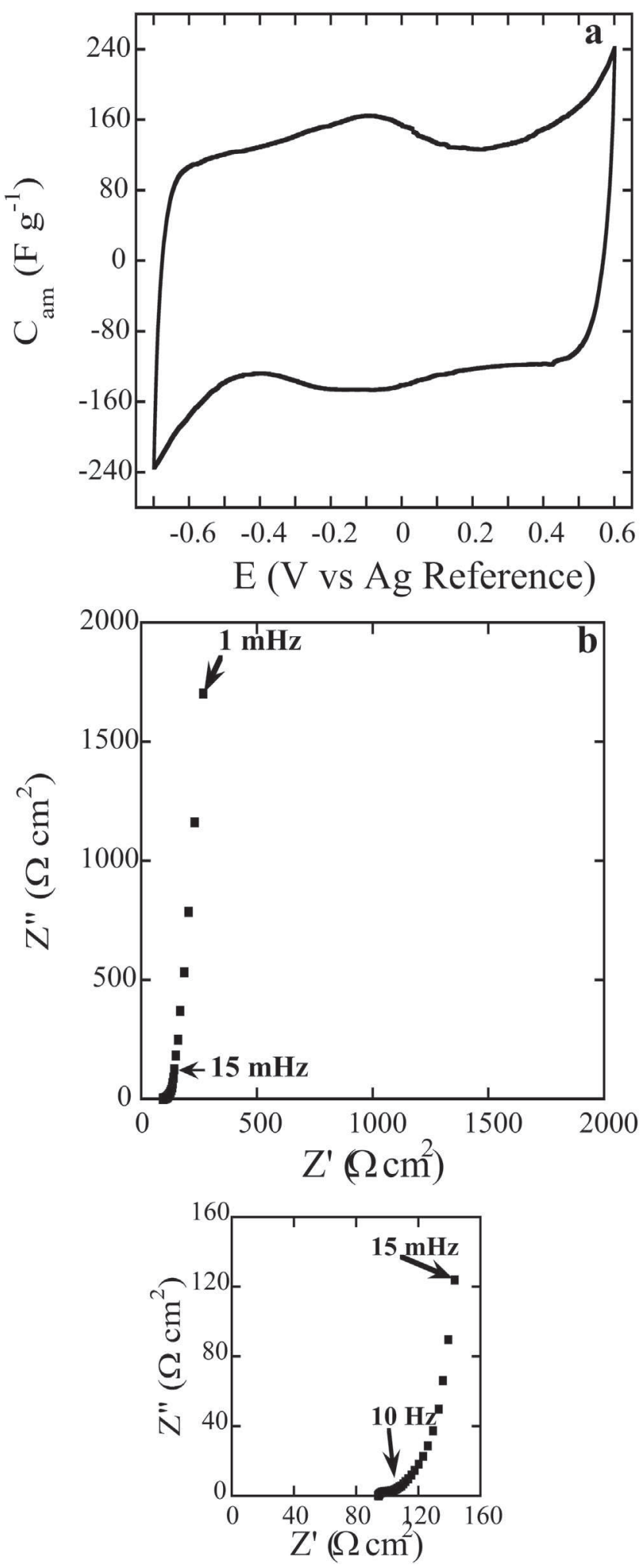

Fig. 5. Room temperature electrochemical characterization of symmetrical supercapacitor with polymer gel electrolyte: a 3-electrode $\mathrm{CV}$ collected at $1 \mathrm{mV} \mathrm{s}^{-1}$ (a) and corresponding Nyquist plot (b).

of 15 wt.\% of diphenyl phosphate was selected because of its reasonable conductivity at low temperatures, $0.073 \mathrm{mS} \mathrm{cm}^{-1}$ at $-20{ }^{\circ} \mathrm{C}$ (that was obviously higher than that found for the systems with higher ester content).

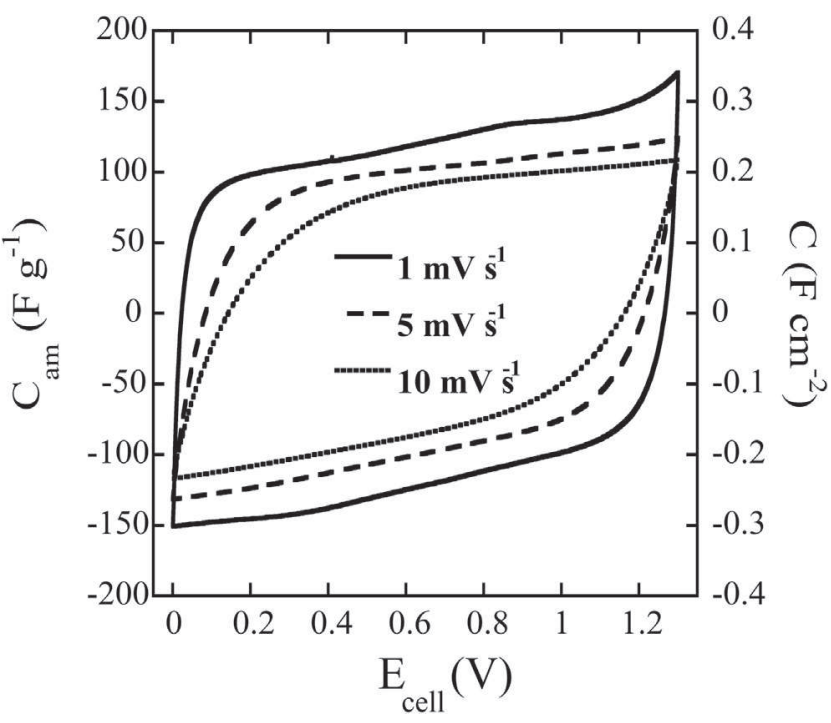

Fig. 6. $\mathrm{CV}$ of symmetrical supercapacitor with polymer gel electrolyte carried out with different scan rate.

Table 2

Capacitance of commercial porous carbon with proton conducting GPE at room temperature.

\begin{tabular}{lc}
\hline Scan rate $\left(\mathrm{mV} \mathrm{s}^{-1}\right)$ & $C_{\mathrm{am}}\left(\mathrm{F} \mathrm{g}^{-1}\right)$ \\
\hline 10 & 89.4 \\
5 & 101.5 \\
1 & 123.0 \\
\hline
\end{tabular}

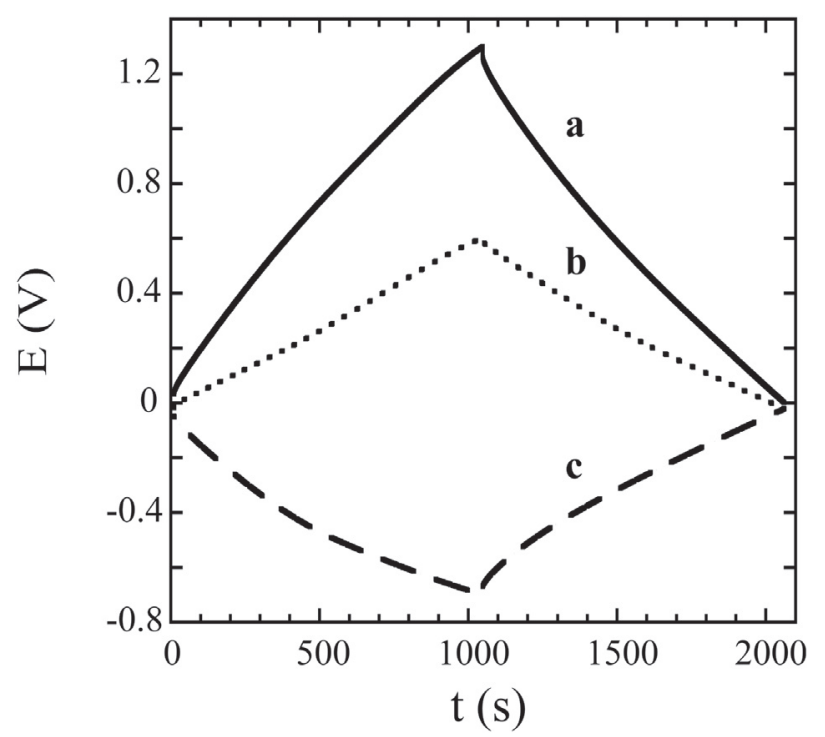

Fig. 7. Galvanostatic charge-discharge curve for symmetrical supercapacitor cell with polymer gel electrolyte collected at room temperature: (a) capacitor cell, (b) positive electrode and (c) negative electrode.

The YP-80F carbon used here has a theoretical specific surface area of $2145 \pm 16 \mathrm{~m}^{2} \mathrm{~g}^{-1}$. The carbon structures contain mainly micropores (pore diameter lower than $2 \mathrm{~nm}$ ) and mesopores in the 2-7 nm diameter range.

Fig. 5a illustrates the cyclic voltammetric response of the YP-80F carbon electrodes coexisting with the diphenyl phosphate-based GPE recorded in a supercapacitor (at $1 \mathrm{mV} \mathrm{s}^{-1}$ ) at room 
Table 3

Equivalent series resistance (ESR), specific capacitance value per gram of average mass $\left(C_{\mathrm{am}}\right)$ for the symmetrical supercapacitor obtained at different temperature

\begin{tabular}{lllcc}
\hline $\begin{array}{l}\text { Temperature } \\
\left({ }^{\circ} \mathrm{C}\right)\end{array}$ & $\begin{array}{l}\text { Cut-off potential } \\
(\Delta E \text { in V })\end{array}$ & $\begin{array}{l}\text { ESR } \\
\left(\Omega \mathrm{cm}^{2}\right)\end{array}$ & $\begin{array}{l}C_{\mathrm{am}}\left(\mathrm{F} \mathrm{g}^{-1}\right) \\
\text { at } 1 \mathrm{mV} \mathrm{s}^{-1}\end{array}$ & $\begin{array}{l}C_{\mathrm{am}}\left(\mathrm{F} \mathrm{g}^{-1}\right) \\
\text { at } 74 \mathrm{~mA} \mathrm{~g}^{-1}\end{array}$ \\
\hline-40 & $0-1.3$ & 947 & 83 & 88 \\
-20 & $0-1.3$ & 350 & 101 & 104 \\
$\mathrm{RT}$ & $0-1.3$ & 95 & 123 & 123 \\
40 & $0-1.2$ & 79 & 150 & 153 \\
60 & $0-1.1$ & 28 & 141 & 144 \\
80 & $0-1.0$ & 25 & 133 & 133 \\
\hline
\end{tabular}

temperature in the three-electrode mode. The minimum potential is found to be $-0.7 \mathrm{~V}$ vs $\mathrm{Ag}$ pseudo-reference electrode, and the maximum one is $0.6 \mathrm{~V}$ ( $\mathrm{vs} \mathrm{Ag}^{+} / \mathrm{Ag}$ ) thus leading to a maximum cell voltage of $1.3 \mathrm{~V}$. The cathodic potential range is defined by the reduction of protons, while the oxidation of the solvent limits the anodic potential range, as already reported by Reiter et al. [43]. The carbon capacitance reaches $120 \mathrm{~F} \mathrm{~g}^{-1}$ in our gel electrolyte, which is probably one of the highest capacitances reported ever for the electrochemical capacitors utilizing microporous carbons in contact with gel electrolytes [20,23,45-47].

Fig. 5b shows the Nyquist plot of the cell (GPE electrolyte in contact with YP-80F carbon electrodes), obtained from the impedance data (performed at $22 \pm 1{ }^{\circ} \mathrm{C}$ ). The vertical increase of the imaginary part of the impedance confirms the capacitive nature of the electrochemical storage. The series resistance measured at high frequencies reaches the value of $95 \Omega \mathrm{cm}^{2}$, which is higher than those reported by Schroeder et al. using ionic liquid-based
GPE, ILGPE [36]. This observation reflected presumably the large thickness $(200 \mu \mathrm{m})$ of our electrolyte and, obviously, the somewhat lower conductivity of our quasi-solid protonically-conducting GPE $\left(0.3 \mathrm{mS} \mathrm{cm}^{-1}\right)$ versus the (more solid) ILGPE $\left(1.8 \mathrm{mS} \mathrm{cm}^{-1}\right)$ at room temperature. It is noteworthy that decreasing the GPE thickness down to $100 \mu \mathrm{m}$ would lead to improvement of the equivalent series resistance (ESR) value.

Fig. 6 shows the cyclic voltammetries (CV) recorded at various scan rates (at $22 \pm 1^{\circ} \mathrm{C}$ ) using a supercapacitor cell with YP-80F carbons and our diphenyl phosphate based GPE. The CV plots have typical (rectangular shaped) capacitive signature. As expected, the gravimetric capacitance $C_{\mathrm{am}}$ has somewhat decreased with the increasing scan rate, namely from $120 \mathrm{~F} \mathrm{~g}^{-1}$ at $1 \mathrm{mV} \mathrm{s}^{-1}$ to $90 \mathrm{~F} \mathrm{~g}^{-1}$ at $10 \mathrm{mV} \mathrm{s}^{-1}$ (see also Table 2), this observation reflects lower ionic conductivity of GPE electrolytes in comparison to liquid ones.

Fig. 7 shows the galvanostatic charge-discharge plots for the cell (GPE electrolyte in contact with YP-80F carbon electrodes) recorded at $75 \mathrm{~mA} \mathrm{~g}^{-1}$ in a three-electrode cell configuration in the potential range from 0 to $1.3 \mathrm{~V}$. All charging-discharging profiles (i.e. characteristic of the cell as well as of each electrode considered separately) show linear-like dependencies of the potential versus time. This observation is in agreement with the capacitive chargestorage mechanism and the capacitance obtained from cycling voltammetry (see Table 3 ).

\subsection{Electrochemical double layer capacitor performance at distinct temperatures}

An important issue is the cell performance at different temperatures, particularly those extreme one. Fig. 8a shows the CVs recorded
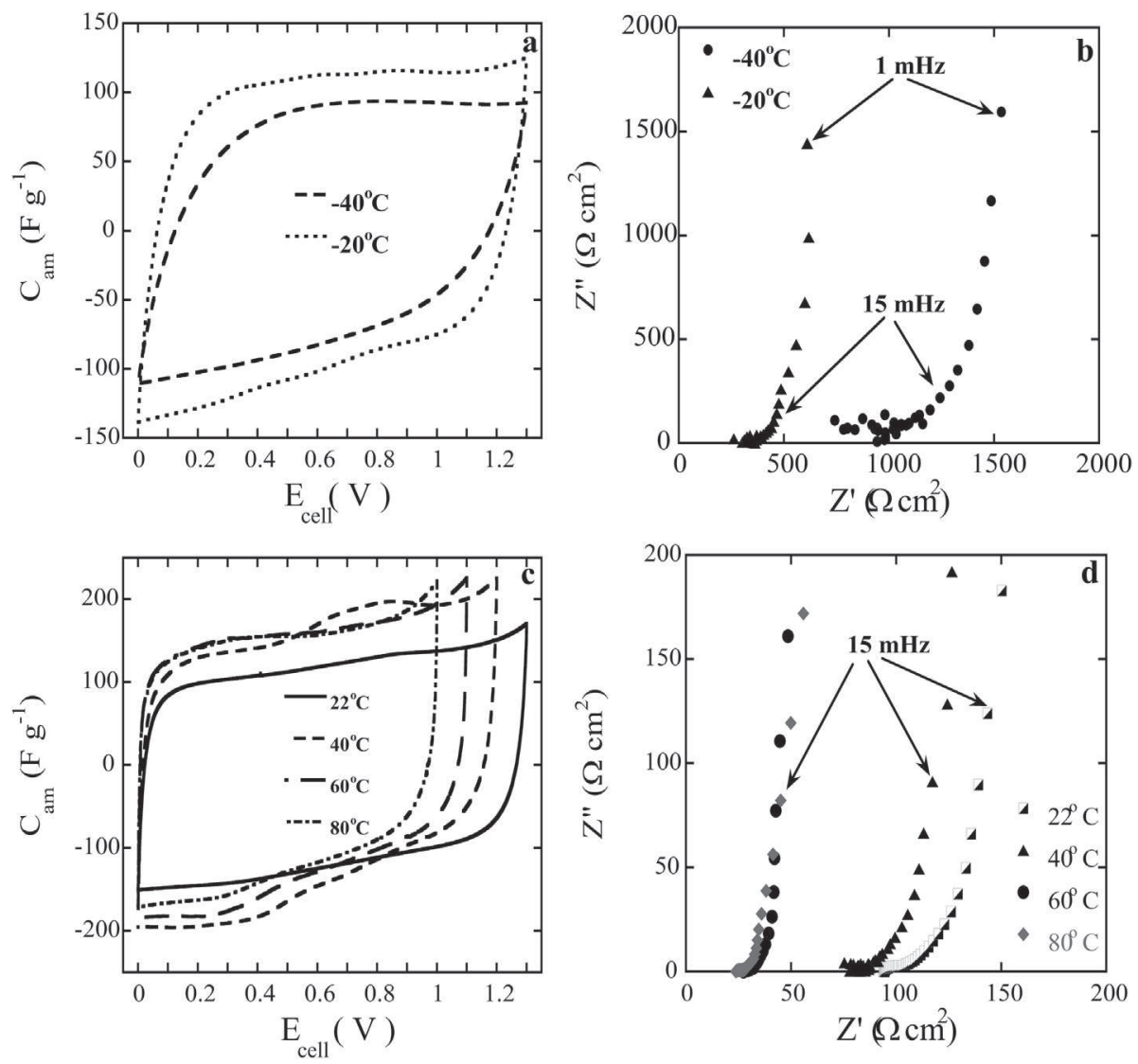

Fig. 8. Electrochemical characterization of symmetrical supercapacitor with polymer gel electrolyte: $\mathrm{CV}_{\mathrm{s}}$ collected at $1 \mathrm{mV} \mathrm{s}^{-1}$ (a), corresponding EIS Nyquist plots (b) at $T<0{ }^{\circ} \mathrm{C}$ and CVs collected at $1 \mathrm{mV} \mathrm{s}^{-1}\left(\mathrm{RT} \leq T \leq 80^{\circ} \mathrm{C}\right)(\mathrm{c})$ and the corresponding EIS Nyquist plot (d). 
at $1 \mathrm{mV} \mathrm{s}^{-1}$ at various temperatures, namely -20 and $-40{ }^{\circ} \mathrm{C}$. The electrochemical signatures are consistent with the typical capacitive behavior with a rectangular shape. The decrease in capacitance at $-40{ }^{\circ} \mathrm{C}\left(80 \mathrm{~F} \mathrm{~g}^{-1}\right.$ versus $120 \mathrm{~F} \mathrm{~g}^{-1}$ obtained at $\left.22^{\circ} \mathrm{C}\right)$ originates from the reduced ion mobility at such low temperature. Nevertheless, $70 \%$ of the initial room temperature capacitance is still retained at $-40^{\circ} \mathrm{C}$ which is remarkable feature of the proton-conducting GPE electrolyte. The fact, that the Nyquist plot (Fig. 8b) shows a sizeable increase in the series resistance $\left(950 \Omega \mathrm{cm}^{2}\right)$ at high frequencies at $-40{ }^{\circ} \mathrm{C}$ relative to the analogous value at $-20{ }^{\circ} \mathrm{C}\left(350 \Omega \mathrm{cm}^{2}\right)$, supports our view about the decrease of ionic conductivity.

The results of Fig. $8 \mathrm{c}$ refer to the capacitance versus cell voltages, analogous dependencies as above, except that the experiments have been performed at higher temperatures, namely at 40,60 , and $80^{\circ} \mathrm{C}$. Obviously, the rectangular-type shapes of curves in Fig. $8 \mathrm{c}$ are consistent with capacitive signatures. The observed increase in capacitance following the increase of temperature reflects obviously the temperature dependent increases in the ionic conductivity or, in other words, results from the improved ionic mobilities at higher temperatures (see Fig. 2b). The smaller $C_{a m}$ value observed at $80^{\circ} \mathrm{C}$ most likely results from the partial DMF evaporation (the solvent's boiling point is $153^{\circ} \mathrm{C}$ [36]). It is noteworthy that, at $80^{\circ} \mathrm{C}$, the maximum system's voltage is effectively reduced down to $1 \mathrm{~V}$ presumably due to increase of the solvent oxidation and reaction rates. Fig. 8d illustrates the Nyquist plots recorded at temperatures ranging from the room temperature $\left(22^{\circ} \mathrm{C}\right)$ up to $80^{\circ} \mathrm{C}$. The decrease in the series resistance from the initial value measured at ambient conditions $\left(95 \Omega \mathrm{cm}^{2}\right.$ ) down to a low value of $25 \Omega \mathrm{cm}^{2}$ at $80{ }^{\circ} \mathrm{C}$ shall be noted and attributed to the system's higher ionic conductivity at $80^{\circ} \mathrm{C}\left(1.1 \mathrm{mS} \mathrm{cm}^{-1}\right.$ as shown in Fig. 2a $)$.

\section{Conclusions}

The proton-conducting Gel Polymer Electrolyte has been proposed, in which as a new proton source, diphenyl phosphate has been used. The application of phosphoric acid ester instead of acid allowed to increase operation voltage window up to $1.3 \mathrm{~V}$ (versus $1 \mathrm{~V}$ for $\mathrm{H}_{3} \mathrm{PO}_{4}$ ) and reach conductivity (at $20{ }^{\circ} \mathrm{C} 3.1 \times 10^{-4} \mathrm{~S} \mathrm{~cm}^{-1}$ ) an order of magnitude higher than for acid. The mechanical properties of GPE permitted to replace separator in capacitor cell.

The electrochemical characterization of EDLC with activated microporous carbon has been carried out with a new protonconducting electrolyte. For the GPE electrolyte, the capacitance of about $120 \mathrm{~F} \mathrm{~g}^{-1}$ (at $22{ }^{\circ} \mathrm{C}$ ), with the maximum voltage window $1.3 \mathrm{~V}$, has been reached. Additionally, the application of organic solvents (PC, DMF) allowed to test capacitor cell in the extreme temperature range (between $-40{ }^{\circ} \mathrm{C}$ and $80{ }^{\circ} \mathrm{C}$ ). In the measurements at $-40{ }^{\circ} \mathrm{C}$, the capacitance reached $80 \mathrm{~F} \mathrm{~g}^{-1}$, which constitutes $70 \%$ of the value obtained at $22{ }^{\circ} \mathrm{C}\left(120 \mathrm{~F} \mathrm{~g}^{-1}\right)$. In higher temperature measurements, at $80{ }^{\circ} \mathrm{C}$, the obtained capacitance is about $133 \mathrm{~F} \mathrm{~g}^{-1}$ with the operation voltage window $1 \mathrm{~V}$. The temperature operation range is significant wide, compared with electrolytes applied in EDLC field before.

\section{Acknowledgments}

The study was supported within the frame of the MPD/2010/4 Project belonging to the MPD Programme of Foundation for Polish Science (co-financed by the European Union, Regional Development Fund) as well as by the Ministry of Science and Higher Education - National Science Centre, Poland under the Project No. NN507322040.

P.S. acknowledges the funding from the European Research Council (ERC, Advanced Grant, ERC-2011-AdG, Project 291543 IONACES), as well as the funding from the Chair of Excellence of the
Airbus Group Foundation "Embedded multi-functional materials" (2012-2017).

\section{References}

[1] B.E. Conway, Electrochemical Supercapacitors - Scientific Fundamentals and Technological Applications, Kluwer Academic/Plenum Publisher, New York, 1999.

[2] R. Kotz, M. Carlen, Electrochim. Acta 45 (2000) 2483-2498.

[3] A. Burke, J. Power Sour. 91 (2000) 37-50.

[4] P. Simon, Y. Gogotsi, Nat. Mater. 7 (2008) 845-854.

[5] E. Frackowiak, Q. Abbas, F. Beguin, J. Energy Chem. 22 (2013) 226-240.

[6] J.C.T. Kyotani, Y. Gogotsi. Carbon Materials for Electrochemical Energy Storage Systems, CRC/Taylor and Francis.

[7] M. Arulepp, J. Leis, M. Latt, F. Miller, K. Rumma, E. Lust, A.F. Burke, J. Power Sour. 162 (2006) 1460-1466.

[8] J. Leis, M. Arulepp, A. Kuura, M. Laett, E. Lust, Carbon 44 (2006) 2122-2129.

[9] J. Chmiola, C. Portet, P.L. Taberna, P. Simon, G. Yushin, Y. Gogotsi, Abstracts of Papers of the American Chemical Society, vol. 231, 2006.

[10] D.N. Futaba, K. Hata, T. Yamada, T. Hiraoka, Y. Hayamizu, Y. Kakudate, O. Tanaike, H. Hatori, M. Yumura, S. Iijima, Nat. Mater. 5 (2006) 987-994.

[11] M. Noked, S. Okashy, T. Zimrin, D. Aurbach, Carbon 58 (2013) 134-138.

[12] C. Portet, J. Chmiola, Y. Gogotsi, S. Park, K. Lian, Electrochim. Acta 53 (2008) $7675-7680$.

[13] C.-M. Yang, Y.-J. Kim, M. Endo, H. Kanoh, M. Yudasaka, S. Iijima, K. Kaneko, J. Am. Chem. Soc. 129 (2007) 20-21.

[14] W.-Y. Tsai, R. Lin, S. Murali, L.L. Zhang, J.K. McDonough, R.S. Ruoff, P.L. Taberna, Y. Gogotsi, P. Simon, Nano Energy 2 (2013) 403-411.

[15] M.-W. Xu, D.-D. Zhao, S.-J. Bao, H.-L. Li, J. Solid State Electrochem. 11 (2007) $1101-1107$.

[16] M. Skunik-Nuckowska, K. Grzejszczyk, P.J. Kulesza, L. Yang, N. Vlachopoulos, L. Haggman, E. Johansson, A. Hagfeldt, J. Power Sour. 234 (2013) 91-99.

[17] V. Augustyn, J. Come, M.A. Lowe, J.W. Kim, P.-L. Taberna, S.H. Tolbert, H.D. Abruna, P. Simon, B. Dunn, Nat. Mater. 12 (2013) 518-522.

[18] V. Khomenko, E. Frackowiak, F. Beguin, Electrochim. Acta 50 (2005) 2499-2506.

[19] R.J. Latham, S.E. Rowlands, W.S. Schlindwein, Solid State Ion. 147 (2002) 243-248.

[20] W. Lu, K. Henry, C. Turchi, J. Pellegrino, J. Electrochem. Soc. 155 (2008) A361-A367.

[21] G.P. Pandey, S.A. Hashmi, Electrochim. Acta 105 (2013) 333-341.

[22] P. Staiti, F. Lufrano, Electrochim. Acta 53 (2007) 710-719.

[23] M. Schroeder, P. Isken, M. Winter, S. Passerini, A. Lex-Balducci, A. Balducci, J. Electrochem. Soc. 160 (2013) A1753-A1758.

[24] I. Stepniak, A. Ciszewski, Electrochim. Acta 56 (2011) 2477-2482.

[25] H. Yu, J. Wu, L. Fan, Y. Lin, K. Xu, Z. Tang, C. Cheng, S. Tang, J. Lin, M. Huang, Z. Lan, J. Power Sour. 198 (2012) 402-407.

[26] Z. Sun, A. Yuan, Chin. J. Chem. Eng. 17 (2009) 150-155.

[27] H. Gao, K. Lian, J. Electrochem. Soc. 158 (2011) A1371-A1378.

[28] H. Gao, K. Lian, J. Power Sour. 196 (2011) 8855-8857.

[29] H. Gao, K. Lian, J. Mater. Chem. 22 (2012) 21272-21278.

[30] H. Gao, H. Wu, K. Lian, Electrochem. Commun. 17 (2012) 48-51.

[31] D. Raducha, W. Wieczorek, Z. Florjanczyk, J.R. Stevens, J. Phys. Chem. 100 (1996) 20126-20133.

[32] J.R. Stevens, W. Wieczorek, D. Raducha, K.R. Jeffrey, Solid State Ion. 97 (1997) 347-358.

[33] M. Morita, J.L. Qiao, N. Yoshimoto, M. Ishikawa, Electrochim. Acta 50 (2004) 837-841.

[34] G. Zukowska, W. Wieczorek, M. Kedzierski, Z. Florjanczyk, Solid State Ion. 144 (2001) 163-173.

[35] R. Lin, P.-L. Taberna, S. Fantini, V. Presser, C.R. Perez, F. Malbosc, N.L. Rupesinghe, K.B.K. Teo, Y. Gogotsi, P. Simon, J. Phys. Chem. Lett. 2 (2011) 2396-2401.

[36] W. Wieczorek, G. Zukowska, R. Borkowska, S.H. Chung, S. Greenbaum, Electrochim. Acta 46 (2001) 1427-1438.

[37] J.C. Lassegues, Proton Conductors: Solid, Membranes and Gel - Materials and Devices, Cambridge University Press, Cambridge, 1992.

[38] K.D. Kreuer, Chem. Mater. 8 (1996) 610-641.

[39] C. Yu, M.H. Davey, F. Svec, J.M.J. Frechet, Anal. Chem. 73 (2001) 5088-5096.

40] Y. Sakai, M. Matuguchi, Y. Sadaoka, K. Hirayama, J. Electrochem. Soc. 140 (1993) 432-436.

[41] M. Pradny, P. Lesny, J. Fiala, J. Vacik, M. Slouf, J. Michalek, E. Sykova, Collect. Czechoslov. Chem. Commun. 68 (2003) 812-822.

[42] D. Cohn, A.S. Hoffman, B.D. Ratner, J. Appl. Polym. Sci. 29 (1984) 2645-2663.

[43] J. Reiter, J. Velicka, M. Mika, Electrochim. Acta 53 (2008) 7769-7774.

[44] L.I. Katzin, G.W. Mason, D.F. Peppard, Spectrochim. Acta Part A Mol. Biomol. Spectrosc. 34 (1978) 57-61.

[45] R.L. Lavall, R.S. Borges, H.D.R. Calado, C. Welter, J.P.C. Trigueiro, J. Rieumont B.R.A. Neves, G.G. Silva, J. Power Sour. 177 (2008) 652-659.

[46] C.-P. Tien, W.-J. Liang, P.-L. Kuo, H.-S. Teng, Electrochim. Acta 53 (2008) 4505-4511.

[47] M. Yamagata, K. Soeda, S. Ikebe, S. Yamazaki, M. Ishikawa, Electrochim. Acta 100 (2013) 275-280. 